\title{
Acute Effects of Alloxan- and Streptozotocin-induced Insulin Deficiency on Somatostatin and Glucagon Secretion by the Perfused Isolated Rat Pancreatico-duodenal Preparation
}

\author{
Y. Goto, M. Berelowitz, and L. A. Frohman \\ Division of Endocrinology and Metabolism, Department of Medicine, Michael Reese Medical Center and The University of Chicago, \\ Chicago, Illinois, USA
}

Summary. The secretion of somatostatin and glucagon by the perfused rat pancreatico-duodenal preparation was examined in situ under control conditions and after the induction of acute insulin deficiency by alloxan or streptozotocin. A $10 \mathrm{~min} 0.625 \mathrm{mmol} / 1$ alloxan perfusion resulted in an immediate and transient increase in basal insulin and glucagon release and a slightly delayed and persistent increase in basal somatostatin secretion. The insulin responses to $16.7 \mathrm{mmol} / 1$ glucose, $1 \mathrm{mmol} / 1$ theophylline, and $19 \mathrm{mmol} / \mathrm{l}$ arginine alone or in combination were virtually eliminated by alloxan treatment. Somatostatin secretion in response to the stimuli was completely inhibited or markedly attenuated. The glucagon-suppressive effect of glucose was unaltered by alloxan and the stimulatory effect of arginine was enhanced. Addition of $1 \mu \mathrm{g} / \mathrm{ml}$ porcine insulin to the perfusion medium did not modify the aiterations in somatostatin and glucagon responses to arginine. Streptozotocin treatment $90 \mathrm{~min}$ prior to the onset of perfusion resulted in changes in somatostatin, glucagon, and insulin responses to glucose and arginine similar to those of alloxan. The present results are consistent with an effect of alloxan and streptozotocin on the $D$ cell similar to that on the B cell, namely, interference with a glucose-mediated effect on hormone secretion.

Key words: Alloxan, perfusion, theophylline, streptozotocin, somatostatin, insulin, glucagon, rat, glucose, pancreas, arginine.

Somatostatin is localized within the pancreas in secretory granules in D cells of the islets of Langerhans $[1,2]$ and its secretion is enhanced by glucose $[3,4]$, theophylline [5, 6], and glucagon [7]. Administration of exogenous somatostatin inhibits the release of insulin and glucagon $[8,9]$. These observations, together with those of $\mathrm{D}$ cell hyperplasia and hypertrophy and of increased pancreatic somatostatin-like immunoreactivity in streptozotocin- and alloxaninduced diabetes in the rat [10-12] and in human insulin-dependent diabetes [13], suggest that somatostatin exhibits an important role in the physiology of islet function and possibly in the pathophysiology of diabetes.

It has recently been reported that plasma somatostatin-like immunoreactivity is elevated in alloxan diabetic dogs [14] and in streptozotocin diabetic rats [15] and that somatostatin secretion from the isolated perfused pancreas of alloxan diabetic rats is exaggerated in response to arginine [16]. In another study, by contrast, normal pancreatic somatostatin responses to arginine, isoproterenol and calcium and a diminished response to glucose were seen in streptozotocin diabetic dogs [17]. The present study was therefore undertaken to investigate further the acute effects of alloxan and streptozotocin on pancreatic somatostatin secretion in the isolated perfused rat pancreas.

\section{Materials and Methods}

Pancreases and attached segments of duodenum from overnight fasted male Sprague Dawley rats weighing 300-350 g, were perfused in situ by a previously described method [6]. All perfusions were performed in pairs consisting of one experimental and one control animal. Perfusion medium consisted of Krebs-Ringer bicarbonate (KRB) buffer containing $0.25 \mathrm{~g} / 100 \mathrm{ml}$ bovine serum albumin and $4.6 \mathrm{~g} / 100 \mathrm{ml}$ dextran (mean molecular weight 70,000 ). The medium was gassed with $95 \% \mathrm{O}_{2}-5 \% \mathrm{CO}_{2}$ and maintained at $\mathrm{pH} 7.4$ and $\mathrm{PaO}_{2} 350 \mathrm{~mm} \mathrm{Hg}$. The flow rate was maintained constant at $2 \mathrm{ml} / \mathrm{min}$ and test materials were introduced through a side arm to provide the desired concentrations. 
Y. Goto et al:: Alloxan and Streptozotocin Effects on Islet Hormones
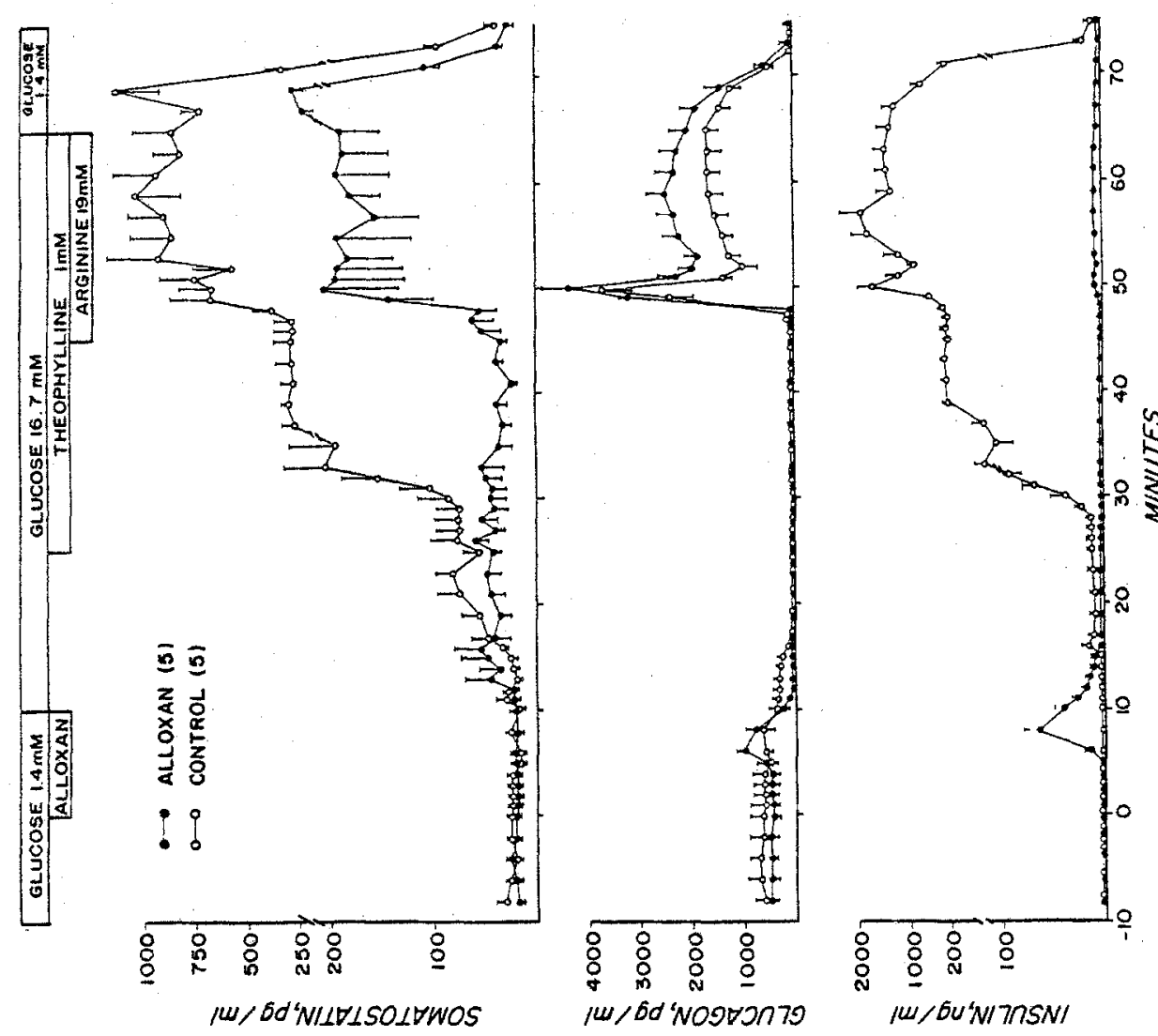

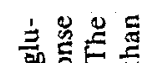

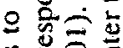

象

동

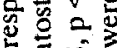

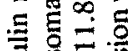

क

車起

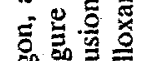

(4)

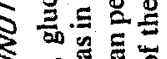

.

क

胥

品 证

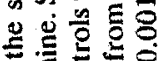

ᄃ․대용

可茟紫的

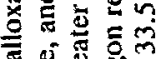

㲅

施语记

这实

(1) 号总

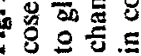
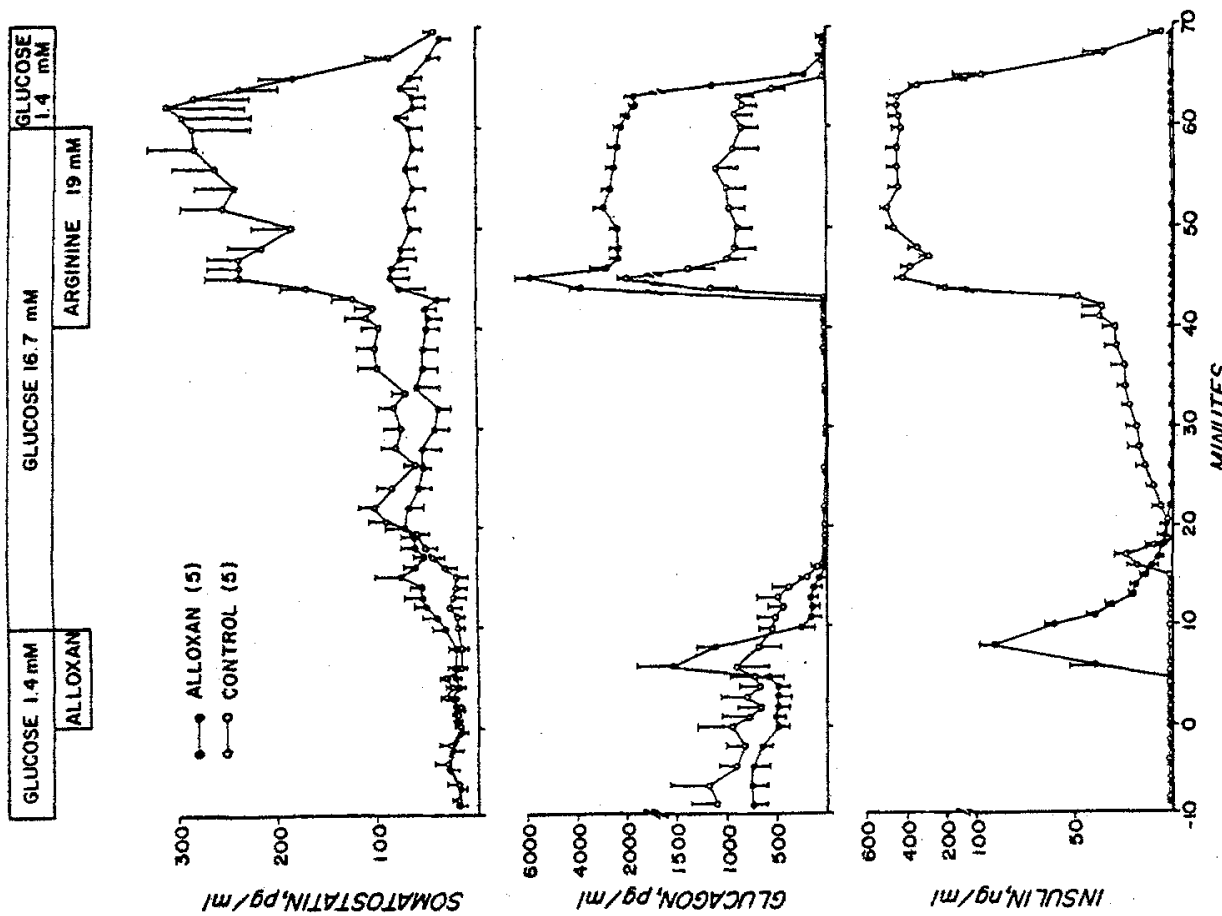

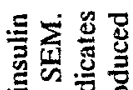

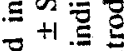

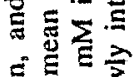

5

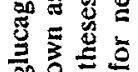

क

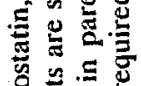

西 的

证

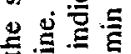

的

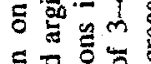

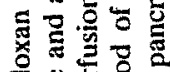

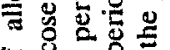

을

矛造《

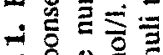

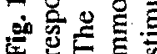



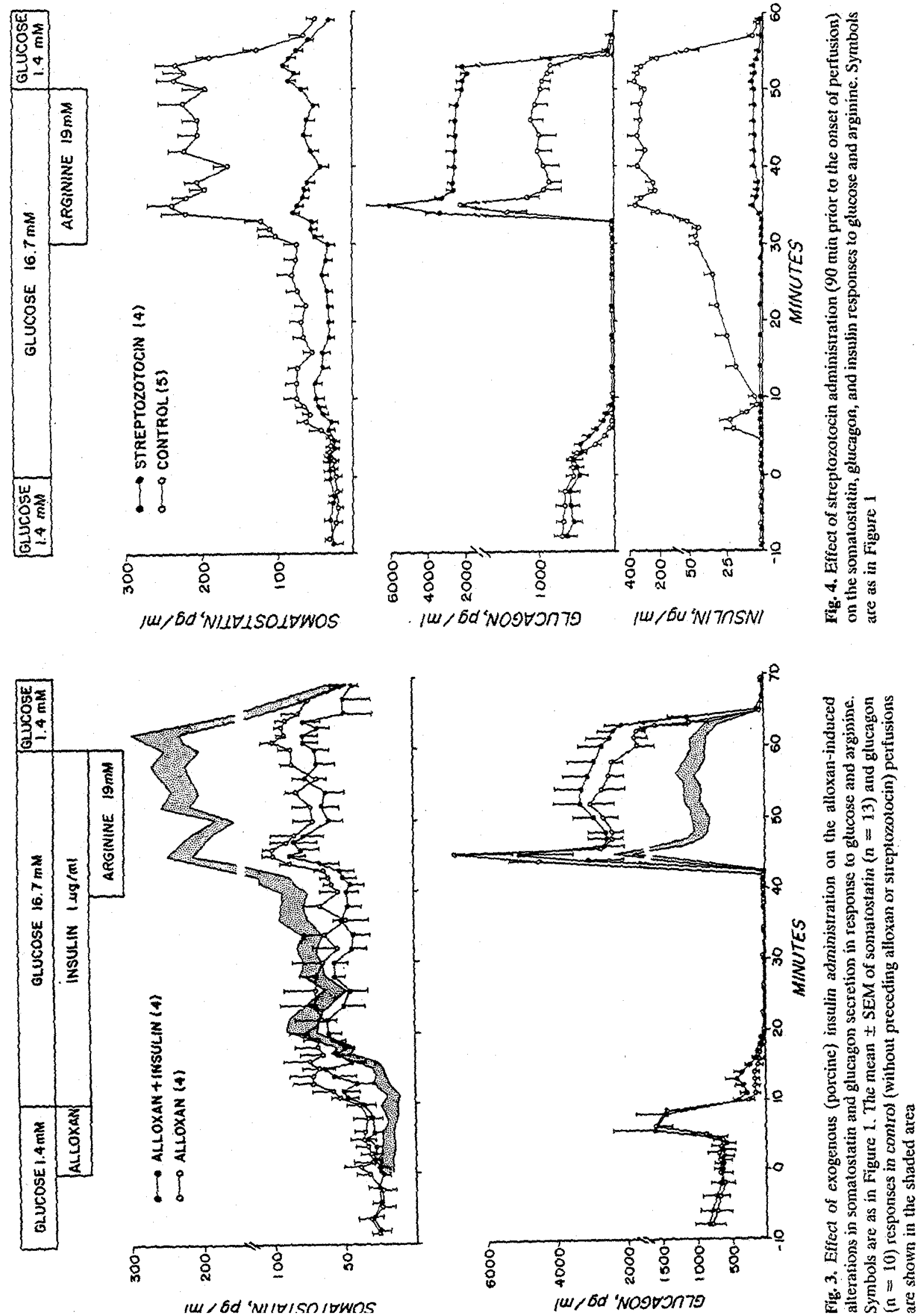
Under the perfusion conditions, a 3-4 min interval was required for newly introduced medium or test materials to reach the pancreas. Aiter a 20 min equilibration perfusion with $1.4 \mathrm{mmol} / \mathrm{g}$ glucose, the following experiments were performed.

\section{Experiment I}

Alloxan monohydrochloride $(0.625 \mathrm{mmol} / \mathrm{l})$ was perfused for $10 \mathrm{~min}$ after which the pancreas was perfused with $16.7 \mathrm{mmol} / 1$ glucose for $30 \mathrm{~min}$, followed by $19 \mathrm{mmol} / 1$ arginine and $16.7 \mathrm{mmol} / 1$ glucose for $20 \mathrm{~min}$. As a control for this experiment, perfusions were performed without the initial alloxan treatment.

\section{Experiment II}

Alloxan monohydrochloride $(0.625 \mathrm{mmol} / \mathrm{l})$ was perfused for $10 \mathrm{~min}$ after which the pancreas was pertused with $16.7 \mathrm{mmol} / \mathrm{I}$ glucose for $15 \mathrm{~min}$, followed by $1 \mathrm{mmol} / \mathrm{l}$ theophylline plus $16.7 \mathrm{mmol} / 1$ glucose for $20 \mathrm{~min}$ and $19 \mathrm{mmol} / \mathrm{l}$ arginine, $1 \mathrm{mmol} / \mathrm{l}$ theophylline, and $16.7 \mathrm{mmol} / 1$ glucose for $20 \mathrm{~min}$. As a control for this experiment, perfusions were performed without prior alloxan treatment.

\section{Experiment III}

The protocol of this experiment was identical to that of experiment II, with the exception that porcine insulin $(1 \mu \mathrm{g} / \mathrm{ml})$ was added during the $16.7 \mathrm{mmol} / \mathrm{l}$ glucose perfusion. Control perfusions were performed without the addition of insulin.

\section{Experiment IV}

In this experiment streptozotocin $(100 \mathrm{mg} / \mathrm{kg})$, dissolved in citrate buffered saline $\mathrm{pH} 4.0$, was injected intravenously seventy minutes before starting the perfusion. After a 20 min equilibration perfusion with $1.4 \mathrm{mmol} / 1$ glucose, the pancreases were perfused with $16.7 \mathrm{mmol} / \mathrm{l} \mathrm{glucose}$ for $30 \mathrm{~min}$, followed by $19 \mathrm{mmol} / \mathrm{l}$ arginine plus $16.7 \mathrm{mmol} / \mathrm{l}$ glucose for $20 \mathrm{~min}$. Control experiments were performed using pancreases from the rats injected with saline.

The effluent from the portal vein was collected at the times indicated in the figures into chilled tubes containing a bacitracinaprotinin mixture $\left(2 \times 10^{-5} \mathrm{~mol} / 1\right.$ and $1000 \mathrm{KIU} / \mathrm{ml}$, respectively), and stored at $-20^{\circ} \mathrm{C}$ until assay.

Immunoreactive somatostatin was determined by a previously described procedure [18]. The assay sensitivity was $15 \mathrm{pg} / \mathrm{ml}$ and serial dilutions of perfusate somatostatin immunoreactivity were parallel to those of synthetic somatostatin. The mean recovery of somatostatin added to the perfusate was $82 \%$. Immunoreactive insulin was determined as previously described [19], using rat insulin as standard. Immunoreactive glucagon was measured as previously described [19] using antiserum $30 \mathrm{~K}$. The sensitivities of the insulin and glucagon assays were $0.1 \mathrm{ng} / \mathrm{ml}$ and $20 \mathrm{pg} / \mathrm{ml}$, respectively. Statistical differences were determined by a two factor anaiysis of variance.

\section{Results}

The Effect of Alloxan on Insulin, Glucagon, and Somatostatin Secretion in Response to Glucose and Arginine (Fig. 1)

The infusion of alloxan caused a transient increase in insulin secretion followed by complete inhibition of the insulin response to $16.7 \mathrm{mmol} / \mathrm{l}$ glucose and to arginine plus glucose. Glucagon secretion was also transiently increased by alloxan (perfusion period $5-8$ min: $F=30.9, P<0.001$ vs control), though the drug did not impair the ability of $16.7 \mathrm{mmol} / 1$ glucose to suppress glucagon secretion to undectectable levels $(<20 \mathrm{pg} / \mathrm{ml})$. The arginine-induced glucagon response in the presence of $16.7 \mathrm{mmol} / 1$ glucose was significantly greater $(P<0.001)$ in the alloxan pretreatment group than in controls.

Somatostatin secretion was not acutely altered by alloxan. However, upon removal of alloxan from the perfusion medium, somatostatin secretion increased to about twice basal levels (perfusion period 10-14 min: $F=9.29, P<0.005$ vs control) and did not respond further to $16.7 \mathrm{mmol} / \mathrm{l}$ glucose stimulation ( $\mathrm{F}=107, \mathrm{P}<0.001$ vs control). The somatostatin levels achieved during the last $10 \mathrm{~min}$ of perfusion with $16.7 \mathrm{mmol} / 1$ glucose were $67 \%$ greater in controls than in alloxan-treated pancreases $(F=18.2$, $P<0.001)$. In response to arginine plus glucose, a slight stimulation was observed though the response was markedly reduced when compared to that of controls $(\mathrm{P}<0.001)$.

\section{The Effect of Alloxan on Insulin, Glucagon, and Somatostatin Secretion in Response to Glucose, Theophylline, and Arginine (Fig. 2)}

Insulin, glucagon, and somatostatin secretion in response to alloxan and to $16.7 \mathrm{mmol} / \mathrm{l}$ glucose in this experiment were comparable to that in Figure 1. Alloxan pretreatment completely ( $>99 \%$ ), inhibited the insulin response to theophylline and to arginine. Alloxan pretreatment did not alter the lack of glucagon response to theophylline observed in the controls but the glucagon response to arginine plus theophylline was significantly increased $(\mathrm{F}=21.9, \mathrm{P}<0.001$ vs controls). Somatostatin secretion was stimulated by theophylline in control perfusions but not in alloxan perfusions. Both groups responded to stimulation by arginine plus theophylline but the somatostatin response was markedly attenuated in the alloxan group $(F=113.9, P<0.001)$.

\section{Effect of Exogenous Insulin on Alloxan Pretreatment-modified Glucagon and Somatostatin Secretion (Fig. 3)}

The effect of correcting the acute insulin deficiency which followed alloxan treatment was assessed by infusing porcine insulin at a concentration of $1 \mu \mathrm{g} / \mathrm{ml}$ during the $16.7 \mathrm{mmol} / \mathrm{l}$ glucose and the glucose plus arginine perfusion. The glucagon and somatostatin responses to the two stimuli were indistinguishable from those in the absence of insulin: the glucagon 
response to arginine remained increased and the somatostatin responses to glucose and to arginine remained absent or markedly suppressed.

\section{Effect of Streptozotocin Pretreatment on Insulin, Glucagon, and Somatostatin Secretion (Fig. 4)}

Insulin secretion in response to glucose and to arginine plus glucose perfusion was markedly reduced after the intravenous injection of streptozotocin. The suppression of glucagon secretion by glucose was not modified by streptozotocin, while the glucagon response to arginine plus glucose was significantly greater after streptozotocin treatment $(P<0.001)$. The somatostatin responses to glucose $(\mathrm{F}=62.9, \mathrm{P}<0.001)$ and to arginine plus glucose $(\mathrm{P}<0.001)$ were significantly reduced by streptozotocin treatment.

\section{Discussion}

The present studies were designed to examine the acute effects of alloxan and streptozotocin on the secretion of somatostatin by the isolated perfused rat pancreatico-duodenal preparation and to compare these responses with those on insulin and glucagon. While these experiments cannot differentiate between a pancreatic or duodenal origin of the released somatostatin, experience in the dog suggests that the duodenal component is not significant [20].

Perfusion with alloxan caused an immediate release of insulin with a subsequent loss of insulin responses to glucose alone or glucose plus arginine and/or theophylline, as has previously been documented $[21-23]$. Glucagon secretion also increased acutely during alloxan perfusion. Following alloxan the inhibition of glucagon release in response to glucose alone or with theophylline was unchanged, while the response to arginine was exaggerated as previously reported in one similar study [23] but not another utilizing a more chronic preparation [17]. This discrepancy may be explained by the more complete metabolic abnormality seen in long term studies. Somatostatin release did not respond abruptly to the onset of the alloxan infusion but rather increased slowly during a five minute period following discontinuation of alloxan. This rise may represent an elevation in basal secretion due to the effect of alloxan, possibly explaining the increased somatostatin release seen in animals with diabetes following alloxan 114,16$]$. An alternate explanation is that the elevation in somatostatin seen soon after alloxan merely represents a more rapid response to elevated glucose. This is less likely, however, as the overall response to $16.7 \mathrm{mmol} / 1$ glucose was decreased. While somatostatin secretion was increased by glucose plus arginine and, more markedly, in the presence of theophylline, these responses were considerably decreased from those in controis.

It has been suggested that endogenous insulin, glucagon and somatostatin act locally within the islet to regulate each others' secretion. If this is correct, it could be argued that the toxic effect of alloxan on insulin secretion removes one regulatory factor from this interaction causing the exaggeration of glucagon release and the decrease of somatostatin release seen in response to arginine and glucose. The failure of insulin infusion after alloxan treatment to influence these responses confirms the data of Hermansen et al. [17] and is evidence against this possibility. The use of heterologous insulin in this experiment cannot explain our result in as much as porcine insulin is fully active in the rat. Alternately, it is conceivable that the $\mathrm{B}, \mathrm{A}$ and $\mathrm{D}$ cells of the pancreatic islets are merely affected differently by alloxan resulting in three different patterns of secretory response which do not reflect a failure of internal regulation.

Streptozotocin treatment resulted in similar changes in insulin and glucagon secretion to those seen following alloxan. Somatostatin secretion following streptozotocin again showed parallelism to that of insulin with a poor response to giucose stimulation alone or with arginine. Previous studies [15, 17] have shown that arginine elicited a normal somatostatin response following streptozotocin. This discrepancy may be accounted for by differences in the time of study after streptozotocin administration. The acute secretory responses to streptozotocin could not be evaluated since the drug was given prior to initiating the perfusion and basal somatostatin secretion was unaltered.

It is of interest to note that the secretion of insulin and somatostatin, normally stimulated by glucose, is decreased following alloxan or streptozotocin and conversely that the secretion of glucagon, normally inhibited by glucose is hyperresponsive following alloxan or streptozotocin. These results suggest that a major effect of these islet cell toxins in mediated by the glucose receptor mechanism.

In conclusion, the present results demonstrate an increase in basal somatostatin secretion in response to alloxan and an impairment in the somatostatin response to glucose, theophylline, and arginine after alloxan or streptozotocin administration. The relationship of these acute effects to islet cell toxins and the persistent increase in somatostatin secretion observed chronically after treatment with these agents will require further study. 
Acknowledgement. These studies were supported in part by USPHS Grant AM20595.

\section{References}

1. Rufener C, Amherdt M, Dubois MP, Orci L (1975) Ultrastructural immunocytochemical localization of somatostatin in D cells of rat pancreatic monolayer culture. J Histochem Cytochem 23: 966-969

2. Alumets J, Sundler F, Hakanson R (1977) Distribution, ontogeny and ultrastructure of somatostatin immunoreactive cells in the pancreas and gut. Cell Tissue Res 185: $465-479$

3. Schauder P, McIntosh C, Arends G, Arnold R, Frerichs H, Creutzfeldt, W (1976) Somatostatin and insulin release from isolated rat pancreatic islets stimulated by glucose. FEBS Lett $68 ; 225-227$

4. Ipp E, Dobbs RE, Arimura A, Vale W, Harris V, Unger RH (1977) Release of immunoreactive somatostatin from the pancreas in response to giucose, amino acids, pancreozymincholecystokinin and tolbutamide. J Clin Invest 60: 760-765

5. Barden N. Alvarado-Urbina, C, Cöte J, Dupont A (1976) Cyclic AMP-dependent stimulation of somatostatin secretion by isolated rat islets of Langerhans. Biochem Biophys Res Commun 71: 840-844

6. Goto Y, Seino Y, Taminato T, Kadowaki S, Chiba T, Note S, Imura H (1970) Theophylline: Potentiation of arginine induced somatostatin release from the isolated rat pancreas. Diabetes 28: 457-459

7. Weir GC, Samols E, Loo S, Patel YC, Gabbay KH (1979) Somatostatin and pancreatic polypeptide secretion. Effect of glucagon, insulin, and arginine. Diabetes $28: 35-40$

8. Koerker DJ, Ruch W, Chideckel E, Palmer J, Goodner CJ, Ensinck, J, Gale CC (1974) Somatọstatin-hypothalamic inhibitor of the endocrine pancreas. Science 184: 482-484

9. Guillemin R, Gerich JE (1976) Somatostatin: physiologic and clinical significance. Annu Rev Med 27: 379-388

10. Patel YC, Weir GC (1976) Increased somatostatin content of islets from streptozotocin-diabetic rats. Clin Endocrinol (Oxf) 5: $191-194$

11. Patel YC, Cameron DP, Bankier A, Malaisse-Lagae F, Ravazzola M, Studer P, Orci L (1978) Changes in somatostatin concentration in pancreas and other tissues of streptozotocin diabetic rats. Endocrinology 103: 917-923

12. McEvoy RC, Hegre OD (1977) Morphometric quantitation of the pancreatic insulin, glucagon and somatostatin positive cell populations in normal and alloxan diabetic rats. Diabetes 26 : 1140-1146

13. Orci L, Baetens D, Rufener C, Amherdt M, Ravazzola M,
Studer P, Malaisse-Lagae F, Unger RH (1976) Hypertrophy and hyperplasia of somatostatin-containing $\mathrm{D}$-cells in diabetes. Proc Natl Acad Sci USA: 73: 1338-1342

14. Schusdziarra V, Dobbs RE, Harris V, Unger RH (1977) Immunoreactive somatostatin in plasma of normal and diabetic dogs. FEBS Lett 81 : 69-72

15. Kazumi T, Utsumi $M$, Yoshino $G$, Ishihara $K$, Hirose $Y$, Makimura $\mathrm{H}$, Baba S (1980) Somatostatin concentration responds to arginine in portal plasma. Effects of fasting, streptozotocin diabetes and insulin administration in diabetic rats. Diabetes 29: 71-73

16. Hara M, Patton G, Gerich H (1979) Increased somatostatin release from pancreases of alloxan diabetic rats perfused in vitro. Life Sci $24: 625-628$

17. Hermansen K, Orskov H, Christensen SE (1979) Streptozotocin diabetes: A glucoreceptor dysfunction affecting $D$ cells as well as $B$ and A cells. Diabetologia 17: 385-389

18. Berelowitz M, Kronheim S, Pimstone B, Shapiro B (1978) Somatostatin-like immunoreactivity in rat blood. Characterization, regional differences, and responses to oral and intravenous glucose. J Clin Invest 61: 1410-1414

19. Frohman LA, Bernardis LL (1971) Effect of hypothalamic stimulation on plasma glucose, insulin and glucagon levels. Am J Physiol 221: 1596-1603

20. Hermansen $\mathrm{K}$ (1980) The role of sodium in somatostatin secretion: Evidence for the involvement of $\mathrm{Na}^{+}$channels in the release mechanism. Endocrinology 106: 1843-1847

21. Tomita T, Lacy PE, Matschinsky FM, McDaniel ML (1974) Effect of alloxan on insulin secretion in isolated rat islets perifused in vitro. Diabetes 23: 517-524

22. Pagliara AS, Stilling SM, Zawalich WS, Williams AD, Matschinsky FM (1977) Glucose and 3-0-methylglucose protection against alloxan poisoning of pancreatic alpha and beta cells. Diabetes 26: 973-979

23. Goto Y, Seino Y, Taminato T, Inoue Y, Kadowaki S, Mori K, Imura $H$ (1978) Modulation by alloxan of glucagon and insulin secretion in the isolated perfused rat pancreas. Endocrinology 102: $1496-1500$

Received: May 20, 1980

and in revised form: September 2, 1980

Dr. L. A. Frohman

Division of Endocrinology and Metabolism

Michael Reese Medical Center

2900 South Ellis Avenue

Chicago, IL 60616

USA 